\title{
Rede na manipulação da democracia no Brasil
}

Network in the manipulation of democracy in Brazil

Red en la manipulación de la democracia en Brasil

Réseau dans la manipulation de la démocratie au Brésil

\section{Tamara Tania Cohen Egler, Thiago Costa Pereira e Fabíola de Cássia Freitas Neves}

\section{(2) OpenEdition \\ Journals}

\section{Edição electrónica}

URL: http://journals.openedition.org/espacoeconomia/17021

DOI: 10.4000/espacoeconomia.17021

ISSN: 2317-7837

\section{Editora}

Núcleo de Pesquisa Espaço \& Economia

\section{Refêrencia eletrónica}

Tamara Tania Cohen Egler, Thiago Costa Pereira e Fabíola de Cássia Freitas Neves, « Rede na manipulação da democracia no Brasil », Espaço e Economia [Online], 19 | 2020, posto online no dia 01 setembro 2020, consultado o 10 setembro 2020. URL : http://journals.openedition.org/ espacoeconomia/17021; DOI : https://doi.org/10.4000/espacoeconomia.17021 


\title{
Rede na manipulação da democracia no Brasil
}

\author{
Network in the manipulation of democracy in Brazil \\ Red en la manipulación de la democracia en Brasil \\ Réseau dans la manipulation de la démocratie au Brésil \\ Tamara Tania Cohen Egler, Thiago Costa Pereira e Fabíola de Cássia \\ Freitas Neves
}

\section{Introdução}

1 Podemos ler a presente conjuntura de crise no Brasil pelo conflito entre dois campos por um lado, o campo progressista e por outro lado o conservador - o que gera uma guerra simbólica, produz uma instabilidade política e divide a sociedade brasileira. Essa divisão é produto de um processo que está sendo produzido a conta-gotas, tal qual uma telenovela, na qual cada capítulo está associado a uma ação política contra a soberania, a economia, e as condições de existência dos pobres do Brasil. Ao mesmo tempo, podemos observar uma retroação (MORIN, 1999), uma resistência, por parte do campo progressista, que podemos compreender através do elo retroativo, ou feedback. A cada dia estamos vivenciando novos fatos vinculados a um processo de alta complexidade, difícil de compreender, sendo nosso objetivo participar do debate para identificar e analisar a mediação de tecnologia de informação e comunicação (TICS) na formação de redes sociotécnicas que estão, por um lado, manipulando, e, por outro lado, defendendo a democracia no Brasil.

2 O exame do lugar da técnica na política remete-nos à identificação das enormes transformações que decorrem de sua invenção. A primeira delas está associada ao avanço da informática, que redefine as relações espaço-temporais e coloca em comum a ação de instituições e pessoas que estão posicionadas em diferentes esferas e escalas, define formas de associação em rede sociotécnica, que associam vitalidades e virtualidades, transversalidades e transescalaridades, e definem formas nunca antes imaginadas de organização política. 
3 Para compreender a crise pela qual estamos passando é preciso considerar a teoria das redes (FOUCAULT, 1999; CASTELLS, 1999, 2009; JOHNSON, 2003; FERGUSON, 2018), que reconhece as semelhanças entre os atores e as afinidades em torno de objetivos compartilhados, quer dizer, quando se compartilha formas de pensar, de fazer e de ser, o que define um campo, como foi formulado por Bourdieu (2007). O que queremos descobrir é o que ilumina e dá significado à rede sociotécnica que associa agentes políticos, econômicos, culturais e sociais em torno de objetivos compartilhados.

4 É nosso objetivo investigar, examinar e revelar o papel crucial que as TICs desempenham no âmbito dessa alternativa de dominação e acumulação. Estamos diante de um processo de transformação da política, em que podemos observar a manifestação de muitos atores, uma comunicação de todos para todos, para a enunciação de discursos políticos que vão além das formas tradicionais de organização política em partidos, sindicatos ou movimentos sociais. As redes que abrem espaço para a emergência de atores políticos são as que queremos descobrir e representar.

5 Nosso objetivo epistemológico é demonstrar como a tecnologia da informação e comunicação - TIC - permite formas de interação entre diferentes atores. Ele exige uma análise interdiscilinar, por interação conceitual (FOUCAULT, 1999), já que a TIC está constituída por diferentes funções que se definem pelos predicados que lhes conferem o poder de alcançar os objetos de ação, sendo nosso objetivo revelar e analisar as redes vinculadas aos dois campos em conflito que atuam no Brasil - aquela que forma o campo autoritário e aquela que forma o campo progressista -, e apresentar dados que demonstram os diferentes processos de manipulação simbólica, dominação política e acumulação de capital.

6 Para levar adiante essa tarefa, elaboramos as seguintes perguntas: Qual é o lugar da TIC na articulação política? Quais são as funções que articulam a rede sociotécnica? Como podemos identificar os atores, processos, fatos associados às redes sociotécnicas? De que forma é possível examinar e analisar o campo conservador e o progressista? Quais dados nos permitem analisar as relações entre os atores e sua associação em rede? Como representar graficamente as redes sociotécnicas? Como a pesquisa pode contribuir para a compreensão dos processos políticos em curso? Quais são os avanços epistemológicos que resultam da pesquisa?

7 Para construir a metodologia, nosso ponto de partida foi aplicar a teoria de Bourdieu (2007) sobre o método de fazer pesquisa em Ciências Sociais: ele orienta a nossa pesquisa para decupar o objeto do conhecimento em objeto empírico e objeto teórico, sendo a totalidade analítica produto dessa associação. Para decupar o objeto empírico, foi necessário identificar os atores, desvendar as diferentes funções, focar nos fatos mais importantes, analisar as narrativas e representar as redes em grafos, que estruturam as diferentes funções. Para decompor o objeto teórico, o primeiro passo é ler e ver a relação entre campo e rede. Como já havíamos alertado em ensaio anterior (EGLER, 2017), a rede sociotécnica é um coletivo que se organiza em torno de sentidos de compartilhamento, colaboração e solidariedade e existe quando tem um objeto de ação em comum. Quer dizer, a rede social é um coletivo concreto ${ }^{1}$, existe no real e no presente, tem um modo de pensar consensual, práticas que resultam da mediação de TICs em torno de objetos compartilhados, o que produz fatos concretos, mensuráveis na realidade, como propõe Ribeiro (2012) , tem existência material, tangível e visível.

8 A categoria campo é uma abstração proposta por Bourdieu $(1998,2007)$ e está associada ao significado de pertencimento a um grupo social que tem um modo compartilhado de 
pensar, ser e agir. É uma das categorias mais importantes na sua obra, porque propõe um novo ponto de observação para interpretar os fenômenos sociais. Quando reconhece os espaços sociais pela produção simbólica que podemos ler no sistema de comunicação, produz o consenso, dá sentido ao mundo e conduz para a integração social. $\mathrm{O}$ desafio proposto pelo autor é aplicar a categoria campo aos universos distintos que têm o mesmo modo de pensamento. Foi o que fizemos, para examinar as diferentes redes de funções.

O desafio é analisar as relações entre a dimensão técnica e social da rede, considerandose que a técnica é formada pela sua dimensão física, informática, e está associada aos computadores, hardware e software, redes de infraestrutura, enquanto a dimensão social deve ser lida na comunicação e interação entre os atores. Aqui está o no górdio de nossa pesquisa, identificar e analisar as relações sociais, que se compreende a partir da integração de corpus (Sinclair, 2018), textos, escritos, provérbios, práticas que produzem a cultura dos seus membros, o seu habitus, como conceitua Bourdieu (1999, 2004, 2007). Quer dizer, como os atores se comunicam, produzem formas de pensar compartilhadas para o exercício de diferentes práticas. $O$ essencial da categoria habitus é revelar o lugar da linguagem em relação à materialidade, ou, aplicado no nosso objeto, analisar as relações entre a dimensão técnica e a dimensão social da rede, que tem materialidade técnica e imaterialidade simbólica, o que nos permite examinar os discursos de seus atores e suas práticas em rede sociotécnica no ciberespaço.

Para produzir os dados e representar as redes, a metodologia usada foi a criação e organização de banco de dados contendo mais de 4.000 artigos, das duas mídias, conservadora e progressista; e o armazenamento dos conteúdos do material selecionado em arquivos formando a base de dados de cada mídia, o que nos permitiu identificar atores e processos e mapear as interações entre funções na rede sociotécnica. Finalmente, utilizamos o programa AntConc para mapear o discurso a favor e o discurso contra (MARTíN-BARBERO 2009).

Os procedimentos metodológicos foram os seguintes:

- produção de banco de dados a partir de informações da imprensa hegemônica e da da imprensa contrahegemônica;

- decupagem do objeto em suas diferentes funções;

- focar a pesquisa em torno de fatos políticos mais importantes;

- identificação dos atores que participam das redes de funções;

- levantamentos, documentação e análise dos discursos pelo programa de informática AntConc;

- representação gráfica da rede por atores e funções, mediante a utilização do programa GEPHI;

- fazer o percurso teórico para identificar categorias e conceitos e iluminar o objeto empírico.

Para construir o objeto empírico foi possível decupar as funções presentes na rede, ler os principais fatos, identificar atores, ler o discurso nos processos de comunicação, e analisar a articulação das diferentes redes. Era preciso focar nos fatos considerados mais importantes, assim, elegemos o impeachment da presidente Dilma Rousseff e o julgamento/condenação do ex-presidente Luiz Ignácio Lula da Silva. Para avançar nessa análise, foi preciso identificar as semelhanças entre os atores associados aos dois fatos. Nos dois casos estão presentes atores que se posicionam a favor do impeachment e atores que se posicionam contra, aqueles que lutam pela condenação e aqueles que lutam pela absolvição de Lula. Para fazer essa demonstração, foram produzidos os 
gráficos que representam as redes sociotécnicas associadas aos dois fatos. É importante lembrar que a comunicação examinada está associada à pesquisa que foi realizada em artigos da mídia que representa o campo conservador e da que representa o campo progressista, não sendo consideradas as outras formas de comunicação como Facebook, Twitter ou WhatsApp.

\section{Funções na rede de manipulação da democracia}

Para decupar o objeto do conhecimento foi necessário representar a sua totalidade no grafo a seguir: são cinco funções que podemos ver e ler nas relações que se estabelecem entre os diferentes atores que participam da ação política que resulta na profunda crise do Brasil. O objetivo é apresentar a complexidade dos atores políticos, econômicos, culturais e sociais no contexto da sociedade em rede, como já havia escrito Castells (1999). Para examinar essa macro rede, nossa tarefa foi reconhecer os principais atores e suas posições no campo, para representar as articulações que associam as diferentes redes e para representar a sua totalidade.

Grafo 1 - Divisão das funções na rede

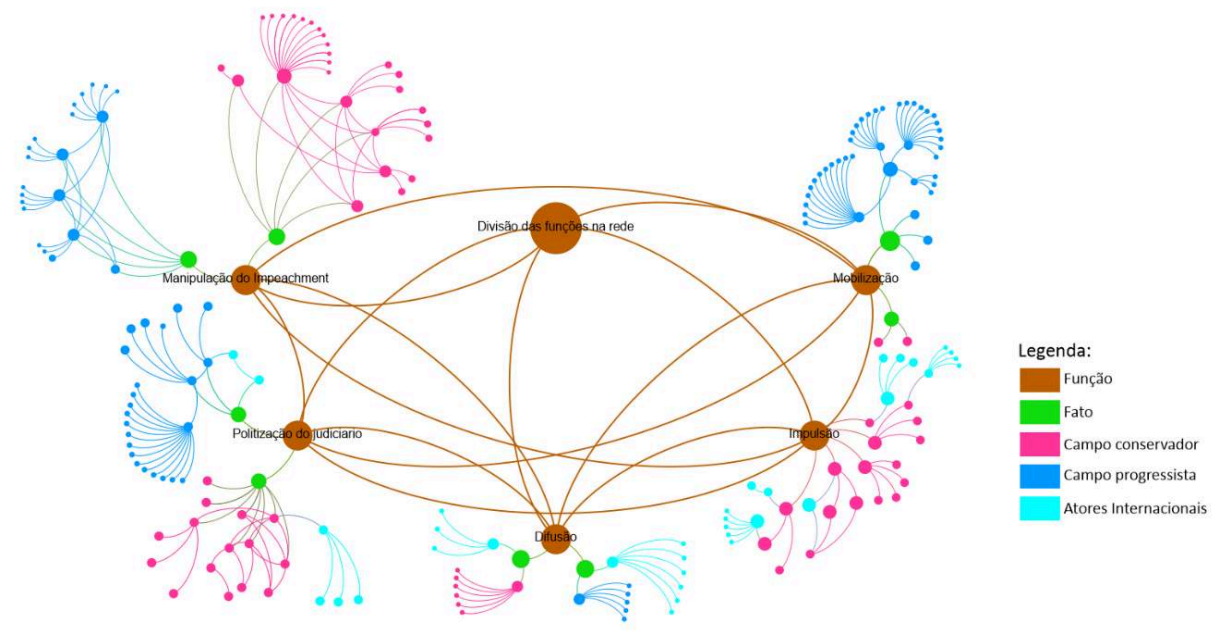

Fonte : elaboração dos autores política; politização do Judiciário; impulsão de poder; difusão e legitimação de discursos; mobilização política. Para produzir a análise optamos por uma estrutura lógica das funções, e seus vínculos analíticos, no sentido de analisar suas práticas no seu habitus e o alcance dos objetivos compartilhados. Para fazer essa demonstração foram produzidos os grafos que representam as redes associados ao impeachment da presidente Dilma e ao julgamento e condenação do ex-presidente Lula.

A rede é formada por diferentes elementos, como a participação de atores associados a grupos identitários, que se organizam em nós, se conectam pela mediação de TICs e conformam relações sociais de comunicação imateriais. A informática os define como hubs, isto é, diapositivo físico que conecta os atores do grupo que formam a rede sociotécnica. Sua tarefa é receber a informação e comunicação e transmiti-la aos outros 
membros do grupo. Trata-se de examinar o conjunto de atores e os vínculos existentes para compreender como se associam os indivíduos e grupos na articulação da rede das redes. Esta é uma estrutura de interconexão instável no tempo, de aspecto dinâmico e decisivo, entretanto pode ser examinada e analisada, sendo possível representar a realidade dos processos que a organizam (PENNA, FREY \& CZAJKOWSKY, 2008).

Para fazer avançar nossa análise, a teoria das redes informa sobre a importância da centralidade, que podemos ler entre categorias: a) centralidade de grau, número de arestas que irradiam de um nódulo específico, trata-se do número de relacionamentos que um indivíduo tem com outros; b) centralidade de intermediação, mede a importância da pessoa na rede e a capacidade que tem por mediar a ação do outro, e permite a inclusão do mesmo na rede; c) centralidade de proximidade, mede o número de etapas que se deve observar para chegar à conexão com a totalidade da rede (FERGUSON, 2018).

Essa articulação se define pela comunicação entre os membros e associa diferentes escalas governamentais, âmbitos estatais - o Executivo, o Legislativo e o Judiciário - e esferas como corporações nacionais e internacionais, mídias hegemônicas e contrahegemônicas, movimentos sociais, todos eles agindo em consonância. São muitas as redes que se sobrepõem e formam uma totalidade de camadas. A mediação da TIC permite uma associação entre diferentes atores, de diferentes esferas e escalas, para articular e fundir numa mesma totalidade poder político, mediático, capitalista e social.

Grafo 2 - Manipulação do impeachment

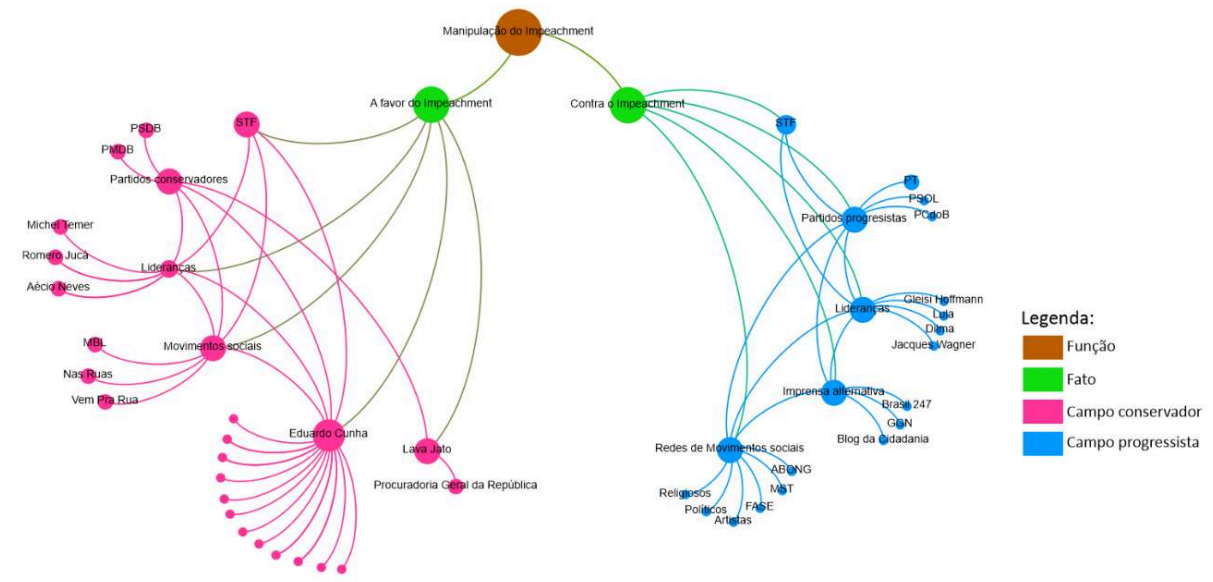

Fonte : elaboração dos autores

o conservador; a cor azul representa o progressista. Seus diversos elemen representam o nosso objeto, que definimos pelos atores, processos e fatos, iluminados pela categoria para designar a função. Ao longo da nossa demonstração iremos usar a mesma identidade de representação das redes e lógica analítica.

Como podemos ler, os nós representam subgrupos como: instituições políticas, mediáticas, sociais e indíviduos que se associam em torno de dois objetivos principais que estamos examinando. O sistema de comunicação é representado pelas arestas, 
linhas que articulam os nós. Quanto maior o número de arestas, maior é a capacidade de comunicação do subgrupo, e sua importância na localização do campo se representa pelo tamanho do círculo.

O impeachment da ex-presidente Dilma Roussef pode ser lido na ação praticada pelo grupo formado por Aécio Neves, Romero Jucá - ambos do Partido da Social Democracia Brasileira (PSDB) -, Michel Temer, vice-presidente da República, e Eduardo Cunha, presidente da Câmara dos Deputados - ambos do Partido do Movimento Democrático Brasileiro (PMDB). Essa ação foi inicialmente tramada pelo senador Aécio Neves, do Partido da Social Democracia Brasileira (PSDB) quando não aceitou ter sido derrotado nas eleições presidenciais de 2014, que reelegeu Dilma Rousseff. Afinal, Aécio declarou publicamente que Dilma não iria governar, que ela não concluiria o segundo mandato. O senador Romero Jucá (PSDB) afirma, em conversa com o ex-senador Sergio Machado, que era preciso "estancar a sangria" ${ }^{2}$ representada pela Operação Lava Jato, que os estava investigando. Nessa mesma conversa, Jucá propôs colocar o vice-presidente Michel Temer na Presidência da República. Estava formado o subgrupo, que produziu o primeiro ato contra a democracia no Brasil (BENTES, 2018).

21 Esse fato produz a atração dos mais importantes partidos políticos, quando os mais importantes líderes de partidos, de corporações, de mídias, entre outros, deram declarações a favor do impeachment, e foi possível observar pelos discursos uma ação orquestrada contra a permanência de Dilma Rousseff na Presidencia do Brasil. Ao mesmo tempo, estavam presentes movimentos sociais de direita - como o Movimento Brasil Livre (MBL) e o Vem para a Rua - que estiveram à frente das mobilizações a favor do impeachment. Quando analisamos o campo progressista, podemos citar partidos progressistas, seus advogados, bem como mídias alternativas e movimentos sociais que lutaram contra o impechment de Dilma Rousseff e pela sua absolvição de Lula da Silva.

O subgrupo formado pelos advogados Hélio Bicudo, Janaína Paschoal e Miguel Reale encaminhou uma denúncia contra a presidente Dilma à Câmara dos Deputados. Eduardo Cunha deu continuidade para a votação em plenário, ficando clara, desde o início, a posição dos partidos opositores ao Partido dos Trabalhadores (PT) - o Partido do Movimento Democrático Brasileiro (PMDB), o Partido da Social Democracia Brasileira (PSDB), o Partido Socialista Brasileiro (PSB) - e outras agremiações menores a favor do impeachment.

23 Nas eleições de outubro de 2014, os parlamentares conservadores fizeram maioria na Câmara dos Deputados. Foi eleito um grande número de ruralistas e religiosos, sobretudo neopentecostais ${ }^{3}$. Em seguida, o deputado Eduardo Cunha foi escolhido, por ampla margem de votos, presidente da Câmara ${ }^{4}$. Sua eleição estava plenamente de acordo com a postura do Congresso, que impedia Dilma Rousseff; paralelamente, a mídia continuava com seu discurso de destruição do PT.

o Executivo conta com deputados e senadores que são maioria no Congresso e asseguram a execução dessa estratégia. Quando aprovaram o pedido de impeachment da presidente Dilma, esses parlamentares, em sua maioria, fizeram discursos com ênfase na vida privada, em detrimento da coisa pública. Essa associação de deputados detém as prerrogativas estatais, o que lhes confere o poder de manipular a lei em benefício de seus interesses privados. Para tanto, exclui-se a participação da sociedade, produz-se uma violência instrumental (ARENDT, 1994) e se permite a manipulação da democracia. 

poder foi necessário associar atores e formar uma rede, que une atores conservadores de muitos poderes, com o objetivo compartilhado de afastar a presidente. Foi elaborado um discurso que alegava "pedaladas fiscais" - prática contábil amplamente utilizada por outros governos e não considerada crime. Era preciso que a sociedade viesse a acreditar nisso para legitimar o discurso que acusou a presidente de ter cometido um crime: um discurso mentiroso, fake news, que não se apoiava em fato concreto ou fundamento jurídico. Para dialogar com Bourdieu (1998), podemos observar que o campo político detém a prerrogativa de elaboração e enunciação de discurso, produz uma representação simbólica que confere significado ao mundo real. A montagem da encenação teatral revela o seu funcionamento, em que a manipulação democratica é decorrente do monopólio de suas prerrogativas.

Ao mesmo tempo, era formulado o discurso contra o impeachment, tendo-se à frente o PT, o Partido Comunista do Brasil (PC do B), o Partido Socialismo e Liberdade (PSOL). Fora do Congresso, integraram as forças antigolpe, a Frente Brasil Popular, que reúne 80 organizações sociais, movimentos sindicais - como a Central Única dos Trabalhadores (CUT), a União Geral dos Trabalhadores (UGT), Central dos Trabalhadores e Trabalhadoras do Brasil (СTB) -, movimentos sociais, organizações da sociedade civil, entre outros. O ministro da Justiça, José Eduardo Cardoso, teve uma importante participação na defesa da presidente Dilma.

Na Câmara dos Deputados o impeachment foi aprovado por 367 votos a favor e 137 contra. Em seguida, o processo foi encaminhado para o Senado, onde a votação, realizada em agosto, registrou 61 votos a favor e 20 contra. Completava-se o ato de manipulação política, e a presidente Dilma foi afastada do exercício do mandato, acusada das tais "pedaladas fiscais". Quando, em nome da lei se aprova o impedimento de uma autoridade que na realidade foi eleita por 54 milhões de votos ${ }^{5}$, entre o dito e o feito, fica a manipulação política em benefício de interesse oculto. Quando toda manipulação é aceita em benefício da rede conservadora, que ao difundir um discurso mentiroso, fake news, se apodera do poder político.

\section{Politização do Judiciário}

A politização do Judiciário, uso perverso do direito, está associada à transferência de competências da esfera jurídica para a esfera política. Isso acontece quando juízes e advogados se arrogam o direito de fazer política, enunciam discursos no espaço público, dando entrevistas à mídia, julgando sem provas, em clara defesa de interesses privados. o desafio é examinar o desígnio da Operação Lava Jato, que focou sua ação, nos últimos três anos, na condenação de Lula. 

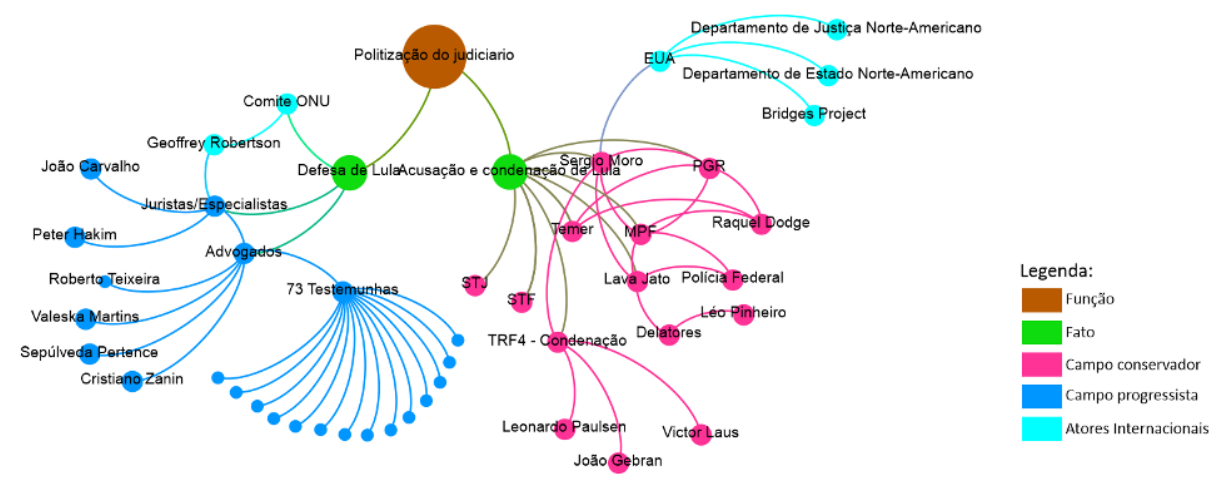

Fonte : elaboração dos autores

Contextualizemos agora o julgamento de Luiz Ignácio Lula da Silva, então potencial candidato à Presidência da República nas eleições de 2018. A partir de delações premiadas, a Operação Lava Jato levou para a cadeia alguns dos principais dirigentes do PT e executivos da Petrobrás, da Odebrecht, da OAS e da JBS. O juiz Sérgio Moro logrou obter uma delação de Leo Pinheiro, presidente da OAS, contra Lula, acusando-o de ter recebido de propina um apartamento triplex, localizado na praia de Guarujá. Ao mesmo tempo, 73 outras pessoas testemunharam a favor de Lula, inocentando-o das acusações do juiz Sergio Moro. Vale lembrar que Leo Pinheiro havia sido incialmente condenado a 34 anos de cadeia; depois da delação, a condenação foi reduzida a três anos.

Como podemos observar no Grafo 3, o Superior Tribunal Federal (STF) está conectado aos dois campos. Quando o processo alcançou essa instância, o pedido de habeas corpus preventivo da defesa foi rejeitado por 6 votos a 5. Com isso, foi autorizada a prisão do ex-presidente Lula, o que dividiu o STF, já que a ministra Rosa Weber votou contra o pedido de habeas corpus da defesa, não julgou a causa, mas defendeu o sentido de corporeidade. A partir dessa condenação, o ex-presidente se entregou e ficou preso numa cela individual na sede da Polícia Federal de Curitiba, jurisdição da Operação Lava Jato. Atuaram na defesa de Lula: o PT; a Frente Brasil Popular; os advogados Cristiano Zanin Martins e Valeska Teixeira Martins, José Roberto Batochio, Sepúlveda Pertence; juristas especialistas; tribunais internacionais; redes sociais presentes no Facebook e no WhatsApp; movimentos sociais que se organizaram em caravanas e mobilizações; mídia contra-hegemônica, como Brasil 247, Tijolaço, Cafezinho, GGN, e tantos outros blogs.

31 Apesar de todas as evidências de que Lula não era dono do imóvel, o juiz Sergio Moro ignorou a argumentação da defesa e condenou o presidente a nove anos e meio de reclusão, na primeira instância. Quando o processo foi encaminhado para a segunda instância no Tribunal Regional Federal, os juízes reiteraram a condenação com um acréscimo da pena para 12 anos e um mês ${ }^{6}$. A leitura das sentenças nos permite pensar como a sentença da primeira instância é reproduzida pelos três juízes do TRF-47

32 A força-tarefa da Lava Jato associa instituições de diferentes esferas, que se unem numa mesma rede sociotécnica. No Grafo 4 estão representados seus três principais nós: 
Procuradoria Geral da República (PGR), responsável por nomear 14 (quatorze) procuradores do Ministério Público Federal, 8 (oito) delegados da Polícia Federal, e o juiz titular Sérgio Fernando Moro da primeira instância da Justiça Federal do Paraná, composta por cerca de 24 membros. Podemos visualizar os membros que dela participam no gráfico a seguir.

Grafo 4 - Operação Lava Jato

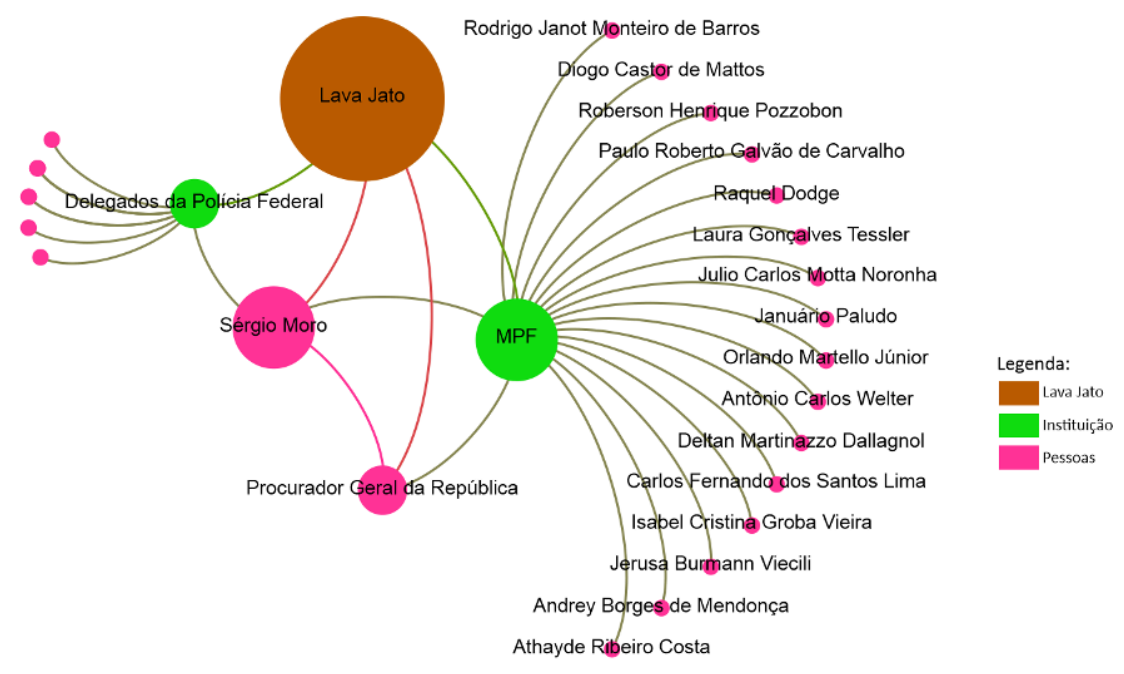

Fonte : elaboração dos autores Nos sites do Supremo Tribunal Federal ${ }^{8}$, do Diário Oficial da União ${ }^{9}$ e do Ministério Público Federal ${ }^{10}$ não encontramos nenhum documento oficial de sua criação. Trata-se de uma força-tarefa que não tem institucionalidade reconhecida pela estrutura de poder jurídico. As primeiras ações da Lava Jato no Paraná possuem decretos disponibilizados pelo $\mathrm{MPF}^{11}$, com linha do tempo e retrospectiva. As suas origens apareceram relacionadas à investigação do Banestado e constitui a ponte para o seu desdobramento. Mas não foi possível identificar nenhum decreto de criação oficial da mesma. Sabemos apenas que a operação começa em março de $2014^{12}$ com a emissão de 81 mandatos de busca e apreensão e 28 prisões.

A operação tem como referência o documento "Manual de Atuação das Forças Tarefas" escrito por seus principais membros e associado à experiência de força-tarefa americana, com a participação de Vladimir Aras, atual procurador geral da República (PGR), recentemente nomeado pelo presidente Jair Bolsonaro (2019-2022). Tudo fica muito grave se considerarmos as relações de compadrio que existem entre juízes e promotores, e o conjunto de agentes governamentais, situados em diferentes escalas, que atuam de forma convergente. Com efeito, a análise realizada possibilitou observar um discurso comum desde o juiz de primeira instância, Sérgio Moro, passando pela 
segunda instância do TRF-4, até uma parte dos juízes do Supremo Tribunal Federal (STF).

Para ler a rede das famílias que participaram da operação, o percurso na literatura nos conduziu para o estudo de sua posopografia (OLIVEIRA et alli,2017), uma biografia coletiva, o que nos permitiu a produção da Tabela 1 e do Grafo 5, nos quais representamos as articulações entre as tradicionais famílias do campo jurídico.

Tabela 1- Rede de articulação entre o político e o jurídico

\begin{tabular}{|c|c|c|}
\hline \multicolumn{3}{|c|}{ Rede Social - Pilares da Lava Jato } \\
\hline Juízes & Políticos & Juristas \\
\hline $\begin{array}{c}\text { Sérgio Fernando } \\
\text { Moro }\end{array}$ & $\begin{array}{c}\text { Oliguarquia Política Macedo do } \\
\text { Pará. Primo do ex prefeito de } \\
\text { Curitiba. }\end{array}$ & $\begin{array}{l}\text { Parente dos desembargadores } \\
\text { Hildebrando Moro e Haroldo Wolff }\end{array}$ \\
\hline $\begin{array}{l}\text { Rodrigo Janot } \\
\text { Monteiro de Barros }\end{array}$ & $\begin{array}{c}\text { Família Histórica Monteiro de } \\
\text { Barros. Família do Visconde de } \\
\text { Congonhas, Ministro da Justiça } \\
\text { do Império }\end{array}$ & $\begin{array}{l}\text { A filha de Janot é uma advogada } \\
\text { que trabalha em um escritório de } \\
\text { advogacia com contratos com } \\
\text { Petrobrás, OAS }\end{array}$ \\
\hline $\begin{array}{c}\text { Deltan Martinazzo } \\
\text { Dallagnol }\end{array}$ & & $\begin{array}{l}\text { Filho do procurador de justiça } \\
\text { Agenor Dallagnol }\end{array}$ \\
\hline $\begin{array}{l}\text { Andrey Borges de } \\
\text { Mendonça }\end{array}$ & & $\begin{array}{l}\text { Irmão do promotor Yuri Borges de } \\
\text { Mendonça }\end{array}$ \\
\hline $\begin{array}{l}\text { Carlos Fernando dos } \\
\text { Santos Lima }\end{array}$ & $\begin{array}{l}\text { Filho do ex deputado estadul } \\
\text { Oswaldo dos Santos }\end{array}$ & $\begin{array}{l}\text { Irmão dos procuradores Luiz José e } \\
\text { Paulo Ovídio }\end{array}$ \\
\hline $\begin{array}{l}\text { Diogo Castor de } \\
\text { Mattos }\end{array}$ & $\begin{array}{c}\text { Sobrinho de Belmiro Castor, ex } \\
\text { secretário de Estado }\end{array}$ & $\begin{array}{l}\text { Filho do ex procurador da justiça } \\
\text { Delivar Mattos }\end{array}$ \\
\hline
\end{tabular}

$\mathrm{Na}$ Tabela 1 se consideram as relações de parentesco em dois campos distintos, o político e o judiciário. Dentre os muitos membros envolvidos na operação, analisamos seis membros, sendo o trio principal - Sérgio Moro, Rodrigo Janot e Deltan Dallagnol -, e num plano secundário, Andrey Borges de Mendonça, Carlos Lima e Diogo Mattos. Essa tabela nos permite perceber como a esfera política e a esfera jurídica fazem parte de uma mesma totalidade. Sergio Moro é membro da oligarquia política Macedo do Paraná, pertence à família de juristas de Hildebrando, casado com Rosangela Maria Wolff de Quadros Moro, da família Haroldo Wolf. Enquanto Deltan Dallagnol e Andrey Borges são filhos de importantes juristas (OLIVEIRA, 2017).

Para fazer a análise da operação Lava Jato é necessário examinar seu habitus no sentido de decifrar sua ideologia, relações familiares, sociais, profissionais, políticas que os associam pelas semelhanças ideológicas e identidades sociais compartilhadas. Tais agentes não podem ser compreendidos dissociados de suas trajetórias e das trajetórias de seus familiares que formam camadas de cultura que se transmite de geração em geração (Bourdieu, 2004). 


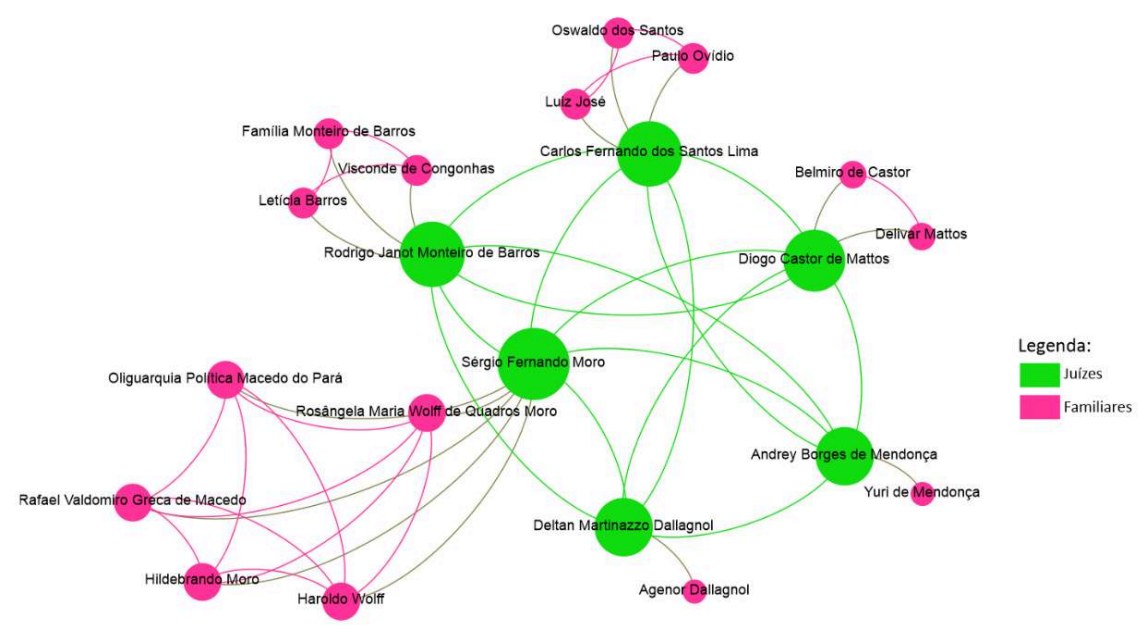

Fonte : elaboração dos autores

Para ler o grafo podemos dizer que o núcleo duro da rede, o seu nó mais importante, esta representado na cor verde; responsável pelo comando da operação. Porque condensam grande poder jurídico e coercitivo, os membros desse comando estão associados numa totalidade que não encontra suporte legal na Constituição. Ao mesmo tempo, podemos observar as relações que eles estabelecem entre parentes do sistema jurídico que representamos na cor rosa. Essa representação nos permite ler a posição de Sergio Moro e esposa quando observamos a origem de Rosangela Maria Wolff de Quadros Moro. Ela fez parte do escritório de advocacia Zucolotto Associados, em Maringá, que defende várias empresas petrolíferas estrangeiras. É membro da grande e poderosa família Manoel Ribeiro de Macedo, do Centro Cívico de Curitiba (OLIVEIRA, 2017).

O comando da Lava Jato se completa com o procurador Deltan Dallagnol, filho do procurador de justiça Agenor Dallagnol, ambos membros da Igreja Batista. Reproduz a estrutura valórica conservadora do pai: autoritarismo e justiça de exceção. Não menos influente é a família de Rodrigo Janot, que tem entre seus membros o ministro do Supremo Tribunal de Justiça no período imperial, Visconde de Congonhas. Porém, é a filha de Janot que mais nos surpreende porque, sendo advogada, trabalha em um escritório de advocacia que defende réus do processo investigado pelo próprio pai, como a Petrobrás. Assim como Diogo Mattos, que é filho do ex-procurador de justiça Delivar Mattos e sobrinho do ex-secretário de Estado do Paraná, Belmiro Castor.

41 Essa rede não deve ser analisada de forma isolada, como indivíduos abstratos, que agem de acordo com o que "diz a lei". São indivíduos concretos que possuem intenções e interesses em suas ações; esse habitus é formado através de camadas de cultura construída no decorrer do processo histórico nas principais instituições que formam as elites jurídicas e as elites políticas do país. Podemos ler sua origem se consideramos como são formados pela mesma escola de Direito da USP, e muitas vezes pós-graduados no exterior, em universidades de língua inglesa. Eles constituem "dinastias jurídicas", agem de acordo com interesses construídos no decorrer de sua formação, o que possibilita em certo sentido desmistificar "o mito das decisões neutras" e de um sistema 
de justiça que atua em consonância com o princípio da imparcialidade e disputa os poderes que constituem o campo judiciário e o campo político pelo controle do poder no Brasil. Por isso, sua oposição ao campo progressista pelo exercício interminável de judicialização da política, pautados pelos seus valores conservadores, quando se usa a justiça em benefício de sua ideologia e de seus interesses políticos, configura-se como oposição a uma ordem libertária, e revela seu ódio à democracia. De mentalidade colonizada, subalterna e entreguista, estão conectados e atrelados às elites do dinheiro, e formam a classe dominante em nosso Brasil (OLIVEIRA, 2017).

Quase todos os membros da rede da Lava Jato possuem bons vínculos e boas relações com a mídia hegemônica, muitos participando ativamente de programas e eventos junto aos principais veículos da mídia dominante do Brasil. Compartilham o mesmo habitus, que podemos ler na participação em solenidades, eventos privados e oficiais em que se encontram, celebram e compartilham os mesmos valores, mentalidades, ideologias e cultura política, de modo que reproduzem de geração a geração as mesmas estruturas familiares dentro das instituições estatais e das empresas privadas, casando com pessoas com perfis sociais, culturais e ideológicos semelhantes (OLIVEIRA, 2017).

Quando vieram a público as revelações do Intercept Brasil, de Gleen Greenwald, tornando conhecidas diversas mensagens trocadas entre Sergio Moro e Deltan Dallagnol, foram demonstradas relações duvidosas na condução da força-tarefa da Lava Jato. Especialmente quando se observa que, de forma secreta e antiética, o então juiz colaborou com os procuradores da operação e participou da formulação do processo para fazer a sua acusação, apesar das sérias dúvidas dos procuradores sobre as provas que poderiam fundamentar essa acusação. À luz das revelações publicadas pela revista Veja, fica evidente o duplo papel de Sergio Moro, de juiz e assistente de acusação, quando, como sabemos, um juiz não pode opinar em negociações com delatores e outros procedimentos que são de função exclusiva do Ministério Público ${ }^{13}$

Os diálogos divulgados revelam como, enquanto continuava a representar o papel de árbitro neutro nesse jogo ${ }^{14}$, o juiz se comportou como chefe do Ministério Público Federal, deixando de lado a imparcialidade e atuando ao lado da acusação. Ele pediu à acusação que incluísse provas nos processos que chegariam depois às suas mãos, mandou acelerar ou retardar operações e fez pressão para que determinadas delações não andassem. Com atuação similar à de coordenador da operação, na privacidade dos chats, revisou peças dos procuradores e os orientou a tornar mais robusta a peça de acusação, participando do estabelecimento de procedimentos jurídicos, dentre outras atitudes que revelam claramente que o juiz atuou em benefício de um dos lados ${ }^{15}$.

Sabemos como na Constituição está escrito: aquele que acusa não pode ser o mesmo que prolata a sentença, e o juiz Sergio Moro atuou ao mesmo tempo em dois lados do processo. Posição incompatível com a neutralidade exigida para um magistrado. As revelações do The Intercept provam os riscos de politização do Judiciário, quando se fazia acreditar que tudo tinha por objetivo combater a corrupção ${ }^{16}$.

Questões acerca da articulação do campo conservador com os interesses internacionais também são levantadas quando consideraras as trajetórias de formação e colaboração com os EUA de algumas das figuras de maior destaque nesse processo de acusação, como no caso do juiz Sergio Moro e do ex-procurador geral da República Rodrigo Janot, cujas interlocuções e assídua colaboração com setores como o Departamento de Justiça e o Departamento de Estado dos EUA ${ }^{17}$ demonstram formas de proximidade e mesmo de subordinação que se coadunam coerentemente com seus comportamento seletivos nas 
instâncias do Judiciário em que atuam. Todos os membros da Lava Jato fazem parte dessa importante rede que levou adiante o julgamento e condenação do ex-presidente Luiz Ignácio Lula da Silva.

\section{Impulsão de poder}

47 Vejamos agora o sentido de impulsão de poder, que, de modo geral, quer dizer alavancar uma coisa que está em baixo e jogar para cima. Essas relações ficam claras quando examinamos, por exemplo, o apoio financeiro de empresários para as campanhas de políticos, ou o apoio de redes para a divulgação massiva das informações de interesse de determinado grupo, ou para a divulgação massiva de notícias favoráveis ou desvavoráveis a personalidades políticas. Vistas em conjunto, as figuras apresentadas a seguir possibilitam observar ao menos parte dessas relações. O Grafo 6 revela relações variadas entre grandes doadores, agências, redes e beneficiários; a Tabela 2 apresenta os deputados que receberam os maiores volumes de recursos no financiamento para a realização de suas campanhas; o Grafo 7 representa os deputados que votaram a favor da reforma da previdência social, caracterizada por medidas claramente favoráveis aos interesses dos empregadores e prejudiciais aos direitos dos trabalhadores assalariados. Os deputados que receberam os maiores volumes de recursos de financiamento das campanhas votaram a favor da reforma da previdência, quer dizer, moeda de troca - se recebe recurso financeiro e vota-se a favor de interesses políticos para favorecer a ação do capital. o que nos permite revelar dados que provam a fusão entre interesses econômicos e políticos, como já está analisado na literatura sobre o tema (HARDT \& NEGRI, 2001; BOBBIO, 2016; CASTELLS, 2017).

Para alcançar seus objetivos, o capital promove a impulsão do Legislativo, financiando as campanhas de deputados e senadores em troca da aprovação de legislação em seu própio benefício. Em outras palavras, o capital exerce essa função de impulsão e participa da rede ao financiar as campanhas e garantir a mudança da lei em benefício de interesses particulares dos atores enredados, e contra a sociedade brasileira. Para fazer essa demonstração foi necessário identificar doadores e beneficiários. Ao mesmo tempo, revelar como os beneficiários votaram pela aprovação da reforma da previdência. 


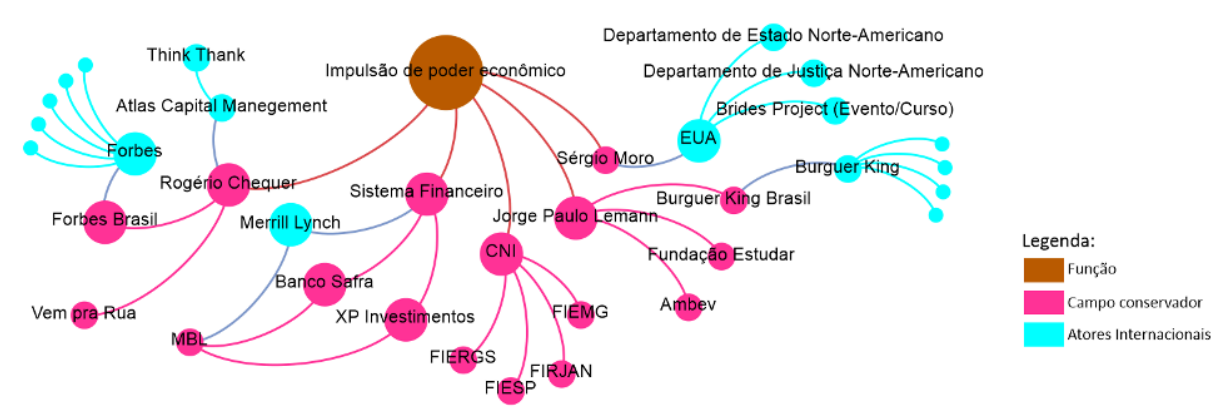

Fonte : elaboração dos autores

Conforme se representa no Grafo 6, podemos observar indicações de importante impulsão de recursos financeiros em apoio aos atores governamentais favoráveis ao impeachment. Esse tipo de apoio financeiro estendeu-se aos movimentos contra o governo Dilma e contra Lula, como, por exemplo, o Movimento Brasil Livre (MBL) e o Vem para a Rua, este último liderado por Rogerio Chequer, sócio da empresa de gestão de fundos de investimentos Atlas Capital Management, e da empresa Discovery Atlas Fund, com US\$115 milhões em ações, e de Robert Citrone, proprietário da revista Forbes, detentor de um patrimônio superior a US $\$ 1$ bilhão ${ }^{18}$.

Além disso, foi possível fazer um levantamento sobre as relações entre doadores e beneficiários, para analisar a participação dos empresários no financiamento de campanhas na eleição de deputados e senadores. Para tanto, foi necessário reconhecer os doadores, suas empresas e valores doados, os partidos políticos e seus candidatos eleitos e não eleitos. No levantamento de dados junto ao Tribunal Superior Eleitoral (TSE) escolhemos examinar os cinco maiores doadores e seus beneficiários.

Tabela 2 - Valores doados e beneficiários

Image

10005964000061610000265EC13FE4B2C10FF8BA.emf Tabela 1 - 10 maiores receptores dos 5 maiores doadores

\begin{tabular}{|c|c|c|c|c|c|}
\hline Valor $\mathrm{R} \$$ & Nome do candidato & Partido & Candidatura & Unidade 日eitoral & Eleito \\
\hline$R \$ 2.005 .000,00$ & GAERIII ROOHAKANN ER & $\mathrm{R} P \mathrm{P}$ & Deputado Federal & SăoPauo & Năo \\
\hline $\mathrm{R} \$ 700.000,00$ & RCORIGOF日INTOIBAPRA EPITAGOMAIA & CEM & Deputado Federal & Pio de Janeiro & Sim \\
\hline $\mathrm{R} \$ 700.000,00$ & ROMEUZBMANETO & NOVO & Governador & Minas Geras & Sim \\
\hline$R \$ 700.000,00$ & RICAPDOCE PEAB NDEFEARACOO & PSDB & Senador & Esárito Sarto & Năo \\
\hline $\mathrm{R} \$ 650.000,00$ & JOÃOAGRIPIN ODA COSTA DCRIAJUNICR & PSDB & Governador & Săo Paulo & Sim \\
\hline $\mathrm{R} \$ 600.000,00$ & ONYXDOFNELESLCFE ZONII & $\mathrm{CBM}$ & Deputado Federal & Rio Grande do Sul & Sim \\
\hline $\mathrm{R} \$ 525.232,00$ & RCEARTOMASSAFERA & PSDB & Deputado Estadual & SăoPaùo & Năo \\
\hline $\mathrm{R} \$ 483.353,20$ & FLAMACAMARGODASILVA & PSC & Deputado Etadual & Săo Paulo & Năo \\
\hline $\mathrm{R} \$ 450.000,00$ & Direção Ețadual/Cistrital - PSB - SÃOPALULO & PSB & Direção Ețadual & São Paulo & \\
\hline $\mathrm{R} \$ 428.615,72$ & EAUNOMARCE ODECIVERALIMA & PG & Deputado Estadual & SăoPau & Sim \\
\hline
\end{tabular}

Fonte : Site do Tribunal Superior Eleitoral-19 
O maior doador é Rubens Ometto, presidente do Conselho de Administração da Cosan, um gigante que fatura quase 50 bilhões de reais e controla a Comgás, maior distribuidora de gás natural do Brasil; a Raízen, terceira maior rede de distribuição de combustíveis do país, em sociedade com a anglo-holandesa Shell; e a Rumo, maior operadora ferroviária da América Latina ${ }^{20}$. É também o detentor de uma fortuna de US\$ 1,4 bilhão com o montante doado no valor de 7,5 milhões de reais. No primeiro turno o empresário apoiou o candidato à Presidência da República Geraldo Alckmin (PSDB) e no segundo turno o candidato Jair Bolsonaro (PSL) ${ }^{21}$

52 A família Rocha, fundadora e detentora majoritária das ações do grupo Guararapes, maior grupo empresarial do ramo têxtil da América Latina, com sede em Natal (RN), também está entre os mais importantes doadores individuais das eleições de 2018. Lisiane Gurgel Rocha e seu pai, Nevaldo Rocha, foram, respectivamente, o segundo e terceiro maiores doadores com os valores totais de 3,5 e 3,3 milhões de reais.

o quarto maior doador é o empresário José Salim Mattar Júnior, dono da empresa de locação de veículos Localiza. Sozinho, Mattar foi responsável por $44,28 \%$ do dinheiro da campanha do candidato Romeu Zema, (Partido Novo), eleito governador de Minas Gerais. Na condição de presidente do Conselho de Administração da Localiza, apoia o Partido Novo e a campanha do candidato a presidente da república João Amoedo. Em 2019, Mattar deixou o posto de presidente da Localiza para assumir a secretaria geral de Desestatização e Desmobilização do governo Jair Bolsonaro, a convite do ministro da Economia, Paulo Guedes ${ }^{22}$

O quinto maior doador é Carlos Francisco Ribeiro Jereissati, que controla diretamente a Shopping Iguatemi e, indiretamente, a Contax Participações S.A. e a Oi Telecomunicações. É também o detentor de uma fortuna de US\$ 1,3 bilhão. Os destinatários que receberam o maior montante das doações de Jereissati foram o candidato Ricardo Ferraço (PSDB), não eleito senador pelo Espírito Santo, e o candidato Rodrigo Maia (DEM), eleito deputado federal pelo Rio de Janeiro, ambos recebendo 700 mil reais do empresário. A família Jereissati tem participação histórica na política brasileira com os políticos Carlos Jereissati (Antigo PRB) e Tasso Jereissati (PSDB), respectivamente, pai e irmão do empresário. As relações entre políticos e empresários são facilmente identificáveis dentro das famílias, e na história do Brasil.

Entre os beneficiários das maiores doações de campanha estão incluídos os diretórios partidários nacionais, estaduais e municipais/distritais e candidatos. 0 maior deles é o candidato Gabriel Rocha Kanner, já citado anteriormente, com o montante recebido de 2,005 milhões; empatados em segundo lugar temos três candidatos, a saber: Rodrigo Maia (DEM), Romeu Zema (NOVO) e Ricardo Ferraço (PSDB), tendo recebido cada um o valor de 700 mil reais. Os 10 maiores receptores estão relacionados na Tabela 2.

Após a reunião dos dados necessários foi possível representar duas redes: a primeira, formada por doadores e beneficiários; a segunda, formada pelos deputados que votaram a favor e contra a previdência. Para fazer essa leitura é preciso considerar que as cores representam as categorias dos atores, conforme legenda, sendo que o tamanho da circunferência representa a quantidade de recursos doados e recebidos. As arestas representam as doações e beneficiários de recursos. 


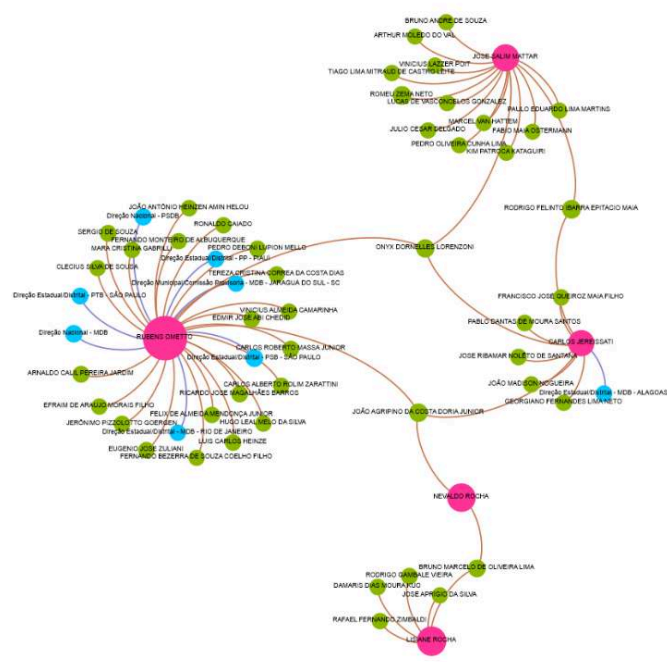

Fonte : elaboração dos autores

Grafo 8 - Deputados que votaram a favor da previdência
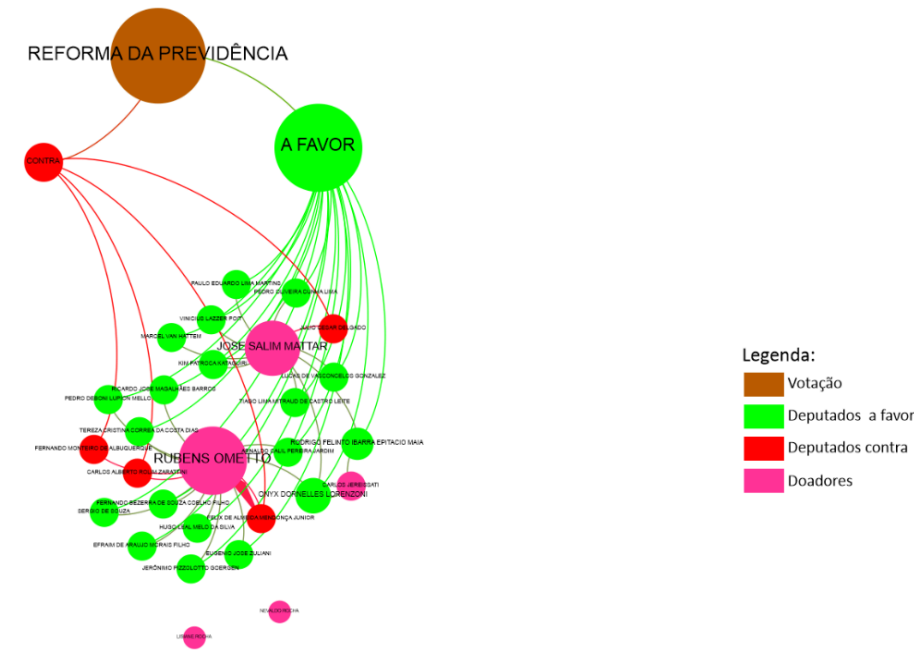

Fonte : elaboração dos autores

57 A representação da rede acima apresenta doadores e voto dos deputados na reforma da previdência. Para ler a rede, o tamanho do nó representa a dimensão dos valores doados, o nó de cor violeta representa os doadores, sendo que o verde representa o voto a favor e o vermelho o voto contra. As arestas de comunicação entre doador e deputado federal indicam uma doação, e aquelas entre deputado federal e voto indicam quem votou a favor e quem votou contra. Como podemos observar pela leitura da representação do grafo, fica claro que a maioria dos deputados que votaram a favor da reforma da previdência são os mesmos que receberam os maiores volumes de recursos das grandes empresas. o que faz a demonstração da nossa hipótese, que associa a rede de impulsão econômica aos atores políticos que foram eleitos nas últimas eleições, e indica o quanto os votos podem estar associados ao "pagamento" dos recursos 
recebidos. Isto evidencia a unificação entre atores jurídicos e econômicos e nos permite demonstrar a importância da função impulsão na rede sociotécnica na produção da crise no Brasil.

Grafo 9 - Difusão e legitimação do discurso

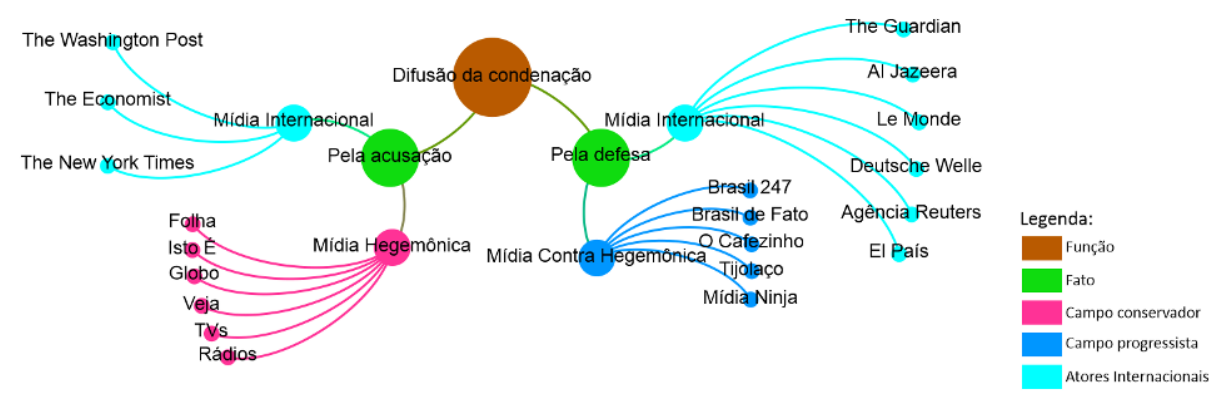

Fonte : elaboração dos autores discursos, valendo-se de diferentes estruturas valóricas para levar adiante a tarefa de contar com a legitimidade política da opinião pública. Por um lado, temos uma mídia hegemônica que tem o poder de difusão televisiva, e de outro lado uma mídia que se vale de plataformas, sites e blogs, e menor poder de difusão, que podemos considerar contra-hegemônica. O campo conservador, agora hegemônico, conduz uma narrativa para destruir o Estado e os direitos humanos, e para enaltecer a violência das armas. Para tanto, há de destruir o discurso do campo progressita a partir de um discurso fake, que ataca e busca desconstruir os valores humanistas e libertários. Enquanto o campo progressita faz a defesa de uma estrutura valórica em defesa dos direitos humanos e das liberdades democráticas, aquele produz o conflito e divide o país em dois, constituído por duas formas de pensar opostas, que podemos ler por uma intersubjetividade que faz a vontade coletiva em cada campo, e tem o poder de fazer a transformação social.

A difusão em apoio à estratégia política remete diretamente à atuação das mídias. Quando os meios conservadores, diuturnamente, a toda hora, em todos os meios de comunicação - mídia impressa, como O Globo, Estadão, Folha, Veja, IstoÉ, e digital desfecharam duros ataques ao PT, a Dilma e a Lula, os mandatos dos dois presidentes petistas foram alvo de intensa destruição, que ganhava representação nas capas, fotografias e textos das publicações.

Com efeito, a responsabilidade da rede de difusão compete aos atores midiáticos imprensa local, as redes de rádio e televisão, as agências de publicidade, e redes sociotécnicas. Coube a esses atores a produção de uma subjetividade coletiva favorável ao golpe, detalhada nos grafos acima. Talvez o exemplo mais acabado tenha sido o discurso acusatório ao presidente Luiz Ignácio Lula da Silva, do juiz Sérgio Moro, sistematicamente destacado e reiterado pelas Organizações Globo e suas subsidiárias. 
Difundiu-se, nesse processo, um conjunto de fatos sem referentes na realidade, fake news, para alcancar o desígnio de produzir uma estrutura simbólica de significados que controlam os sentidos políticos, legitimam o discurso acusatório e conduzem a ação política dos indivíduos na sociedade. Melhor, produz uma subjetividade coletiva desfavorável ao PT e as suas principais lideranças, e conduz a ação política de uma grande maioria da população brasileira, em benefício do campo conservador.

61 Podemos dizer que as fake news distorcem a realidade. Podem ser percebidas como informação falsa, mas, apresentadas como fatos reais, são publicadas e disseminadas em mídias. Apesar de o termo "falso" sugerir uma inverdade absoluta, há gradações, podendo se tratar de uma falsificação, um exagero de informação, uma especulação, opinião manipulada, uma distorção. É preciso esclarecer: fake news são inverdades ditas desde muito tempo, dessa vez sob nova roupagem. Utilizam principalmente o sensacionalismo como estratégia: trata-se de informação publicada sem as devidas apurações, verificações e análises (Martín-Barbero, 2009). Elas manipulam os sentidos de quem não percebe a distinção entre o real e o simbólico, e acreditam em toda e qualquer notícia falsa. Com Marcia Tiburi (2019) podemos pensar ser uma negação da realidade, uma designação negativa com propósito político, um delírio de poder; por não ter existência própria, tem por objetivo destruir a realidade para existir.

Para alcançar seus objetivos a mídia produz storytelings, pequenas estórias que se assemelham a capítulos de telenovelas, apresentando a cada dia um fato novo, técnica de controle e de poder para manipular a opinião pública e produzir a legitimidade dessa ação política. Beneficiam-se dela o governo, as corporações internacionais, o capital financeiro, todos aqueles que sustentam sua emissão por patrocínios e interesses compartilhados. Trata-se da construção planejada de uma narrativa fantasiosa com aparência de realidade, para criar a sensação de participação consciente e cidadã (SALMON, 1999; BENTES, 2018; VAN DIJK, 2017). Ela representa poderoso processo de comunicação e atração de agentes para a manipulação da democracia, uma verdadeira máquina publicitária que leva adiante a tarefa de constituir a legitimidade da política junto à sociedade.

\section{Mobilização social}

Não menos importante foi a resistência social, tanto do campo conservador, quanto do progressista. No Grafo 10, estão representados os principais atores que participaram da mobilização política nos dois campos. Por um lado, vamos identificar uma grande mobilização social por conta do julgamento e condenação do ex-presidente Lula. Fica clara a importância das caravanas, que alcançaram manifestar o apoio de importante parcela da sociedade brasileira ao ex-presidente. Ao mesmo tempo, podemos citar a mobilização desencadeada pelos movimentos sociais de direita, que, antes e depois do impeachment, tomaram conta das praças públicas e das redes sociotécnicas para se manifestar contra a presidente Dilma Rousseff e exigir a sua deposição. 


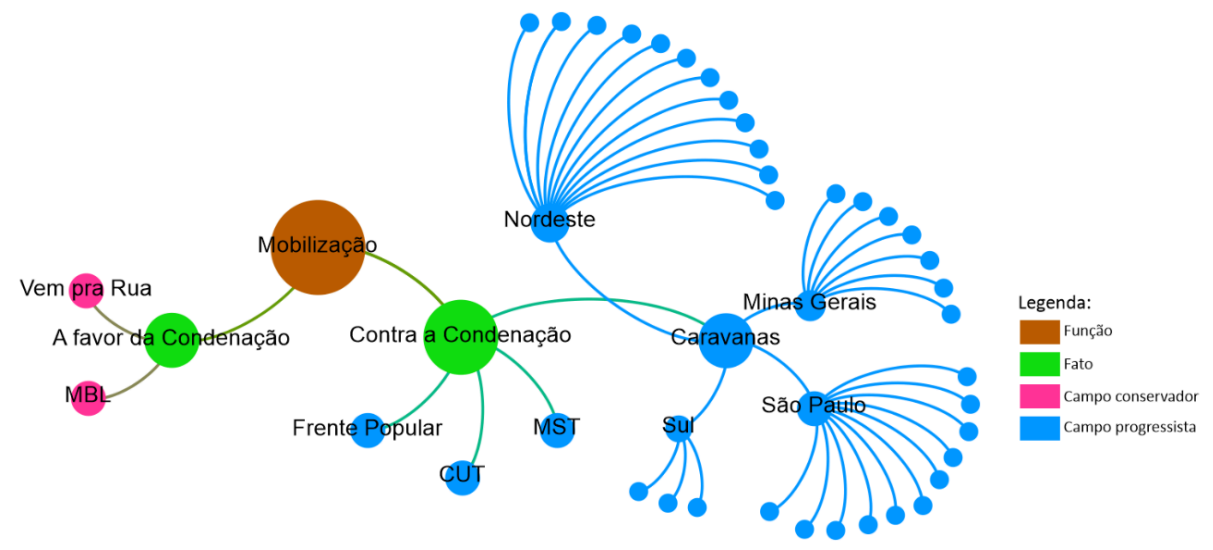

Fonte : elaboração dos autores manifestações, ganhando o apoio de uma boa parte da classe média e mobilizando um expressivo número de "batedores de panelas" que exigiam o afastamento de Dilma. No Gráfo 10, podemos ler como o MBL tem uma ideologia neoliberal e mantém importantes relações com partidos de direita. Começou no final de 2014 como um grupo que se dizia apartidário e anticorrupção para pedir o impeachment de Dilma Rousseff. Depois, passou a se associar a partidos de centro-direita, como o DEM, ao mesmo tempo em que se expandia nas redes e se colocava como tropa de choque de pautas conservadoras. Teve importantes resultados ao fundar um movimento social de direita a partir de táticas desenvolvidas pela esquerda. Com certeza é um movimento social inusitado que soube construir um discurso que se revelou importante no contexto político que fez o impeachment, bem como o julgamento e a condenação de Lula. Seu poder político pode ser lido nas últimas eleições, quando lideranças como Kim Kataguiri e Arthur do Val foram eleitos, respectivamente, para deputado federal e deputado estadual por São Paulo, e estiveram entre os mais votados. 

liderado por Fábio Ostermann e Juliano Torres, membros dos Estudantes pela Liberdade, a filial brasileira do movimento Students for Liberty, dos EUA. Eles têm laços estreitos com outras organizações internacionais, como a Atlas Network, que forma uma rede entre mais de 400 organizações liberais de vários países do mundo. A Atlas Network também é importante nessa história toda, porque ela financia seus parceiros com cursos, treinamentos e patrocínios. A sua função é "nutrir" movimentos nas diferentes nações do mundo alinhados com o liberalismo econômico. Está associada a diferentes institutos, sendo o mais conhecido o Millenium - que tem participação de órgãos da imprensa conservadora como Grupo Globo e Grupo Abril. Todas essas organizações, além de outras dezenas de think tanks, difundem ideias liberais e formam uma opinião favorável ao livre mercado, às privatizações, à redução do papel do Estado, entre outros ${ }^{24}$.

A história da Atlas Network é marcada pelo seu profundo impacto na ideologia e nas relações de poder político em diversos países. Os think tanks associados à Atlas são discretamente financiados pelo Departamento de Estado e o National Endowment for Democracy (Fundação Nacional para a Democracia - NED), braço crucial do soft power norte-americano. A NED e o Departamento de Estado, que contam com entidades públicas que funcionam como centros de operação e propagação de ideias, como a Fundação Pan-Americana para o Desenvolvimento (PADF) em sua sigla em inglês, a Freedom House e a Agência de Desenvolvimento Internacional dos Estados Unidos (USAID), são os principais entes que distribuem as diretrizes e recursos. Conta com 450 fundações, organizações e grupos de reflexão e pressão, com um orçamento operativo de 5 milhões de dólares (2016), entregues por suas fundações "sem fins lucrativos", e que apoiaram o MBL. O Instituto Millenium é um think tank jurídico do Rio de Janeiro que promove atividades para favorecer soluções de livre mercado no Brasil. $\mathrm{O}$ grupo, fundado em 2006, recebe financiamento de várias grandes corporações com sede no país: Bank of America, Merryll Lynch, Grupo RBS, Gerdau e o Am-Cham Brazil, o grupo de empresas estadunidenses no país. O Millenium foi particularmente ativo na promoção de manifestações contra a presidente Dilma Rousseff ${ }^{25}$.

Um segundo desafio epistemológico é demonstrar a importância dos discursos que formam a cultura e transformam a política, como está escrito na obra de Ana Clara Torres Ribeiro (2012), que passou sua vida estudando a ação política imanente, essa que se origina dos indivíduos. Para analisar as práticas de resistência e insurgência contra a cultura dominante, seu ponto de partida foi examinar o sujeito em seu contexto, e para tanto, desde logo ela anuncia a importância de se estudar os meios de comunicação na formação da consciência coletiva, considerando, entre outros aspectos, a criação de imagens que não correspondem à realidade. Ao examinar a tensão entre o simbólico e a realidade da experiência, ela demonstra como se alteram os processos de dominação que exigem de nossa parte uma nova teoria para dar conta da complexidade de atores, processos e fatos que acontecem na conjuntura da globalização. Para além das relações de dominação econômica, propõe uma análise que incorpore a dimensão simbólica da linguagem na análise da política, para iluminar como se intensifica o intercâmbio dos vínculos sociais e das conexões entre atores políticos, capital financeiro, cultura e movimentos sociais.

70 O campo progressista conduz uma ação que acontece nos fatos, na realidade, no espaço público vital, ao vivo, corpo a corpo, a partir de eventos que fazem a estória do lugar e 
das suas pessoas, enquanto o campo conservador atua principalmente na enunciação de um discurso fake, mentiroso, de destruição do outro, ocultando a verdade. Sendo que o campo conservador ganhou a guerra quando elegeu Jair Bolsonaro para a Presidência da República. tem por objetivo provocar a instabilidade política interna no país, pelo conflito de narrativas em redes sociais. É do conhecimento de todos que os EUA desenvolvem, e de forma continuada, uma política de interferência aberta e secreta nos assuntos internos de outros países. Sob o discurso mentiroso de preocupação com os direitos humanos e a democracia, Washington ataca diretamente a soberania de outras nações, principalmente quando está em jogo a apropriação de recursos naturais.

A presença dos interesses americanos no Brasil foi denunciada por Julian Assange quando publicou documentos secretos do governo americano, no conhecido Wilkileads, e por Edward Snowden, que revelaram fatos que atestavam cabalmente a espionagem americana contra lideranças políticas e econômicas no Brasil. A cumplicidade entre atores globais e locais é de extrema importância, uma vez que para intervir nos países os atores globais precisam de atores locais para mudar as leis em seu benefício, como ja havíamos analisado anteriormente (EGLER, 2017). Era preciso tirar o país da articulação dos BRICs, organização formada por cinco países emergentes - Brasil, Rússia, Índia, China e África do Sul -, que pretendia instaurar uma bipolaridade em relação ao eixo que reúne os EUA e a Europa Ocidental. Torna-se evidente a forma pela qual os atores locais, públicos e privados, estão associados ao poder de atores globais, públicos e privados, e produzem um conflito simbólico nas redes sociotécnicas, para causar instabilidade no país, tendo como meta trocar o regime do país para a direita, e favorável aos interesses dos EUA. Trata-se de desestablizar as nações, a partir da enunicação de discursos associados a estruturas valóricas contraditórias e difundidas 
pelas redes sociais, o que acaba produzindo a divisão da nação em dois campos (KORYBKO, 2018), como aqui apresentados, o autoritário e o progressista.

77 Esse método já foi utilizado em outros países. O documentário Privacidade Hackeada, apresenta com detalhes essa estratégia e demonstra os resultados alcancados nas eleições de Trump ( 2016), no Brexit ( 2019), na Inglaterra e no Brasil ( 2016), entre outros países. É um método que alcança seus objetivos de dividir internamente os países em dois grupos, jogando uns contra os outros, desenvolvendo-se a partir de práticas de cooptação de atores locais, que se responsabilizam pela divisão local, e que envolvem segmentos variados de atores, como do judiciário, políticos, de variadas frações do capital e mídias, como apresentamos no desenvolvimento da análise realizada.

\section{Concluindo}

Os vários aspectos aqui apresentados nos permitem compreender como essa rede vitoriosa do campo autoritário está empenhada em produzir uma ação que se desenvolve a partir da politização do Judiciário, ancorada na impulsão de diferentes atores, pela difusão de um discurso por mediação de TICS e por uma mega rede sociotécnica que legitima uma forma de pensar conservadora. Para que isso tenha resultados efetivos, faz-se necessário o exercício de uma justiça politicamente posicionada, para produzir fatos mentirosos corporificados nas delações de empresários e políticos, obtidas pelas manipulações de juízes contra os partidos de esquerda e pela condenação de suas mais importantes lideranças.

o poder desssa megarede sociotécnica resulta de uma organização que unifica poder político, jurídico, econômico e midiático para o objetivo compartilhado de destruir a democracia e auferir os ganhos econômicos sobre a totalidade da nação brasileira. Essa poderosa organização tem encontrado uma forte resistência da parte do campo político progressista, formado pela mídia contra-hegemônica, por mobilizações e caravanas, redes sociais e partidos políticos. Esse conjunto de atores é responsável pela enunciação de um discurso que se opõe ao processo de dominação em curso, e visa a legitimar os anseios de uma sociedade democrática junto à opinião pública.

Podemos observar, a olho nu, como o poder da rede conservadora é maior do que o poder da rede democrática . Existe uma conexão entre as diferentes escalas e esferas associadas ao mesmo discurso acusatório, tanto no impeachment da Dilma Rousseff quanto no julgamento doex-presidente Lula da Silva. Os atores midiáticos são os mesmos - Rede Globo, Folha de S. Paulo, Estadão, outras TVs menos importantes, rádios -, todos associados em torno de um discurso de condenação (VAN DIJK. T, 2017). A mídia produz a difusão de uma imagem destinada a formar uma subjetividade coletiva acusatória de Dilma e de Lula, manipular a opinião pública, produzir a legitimidade da ação política e, assim, garantir o principal objetivo do golpe: o impedimento de Lula como candidato à Presidência da República nas eleições de outubro de 2018.

81 A mídia hegemônica têm a função de atribuir legitimidade à política do Estado e das elites financeiras, visando a proteger, com isso, os interesses da acumulação dos ricos, e prejudicar os pobres. É uma guerra simbólica dos ricos contra pobres; de políticos e juízes contra professores e artistas; de partidos conservadores contra partidos progressitas; de movimentos sociais de direita contra movimentos sociais de esquerda; 
de parte da população brasileira contra outra parte; ela prescinde de aviões e tanques, metralhadoras, tiros e mortes.

O pior de tudo, e como ja havia dito Korybko (2018), no seu precioso Guerras Híbridas, o campo progressita não tem a compreensão do funcionamento e extensão desse método. É urgente a tarefa de fazer frente à rede do campo conservador. Para tal, deve ser capaz de sair da disputa entre pares para formar uma rede de poder que inclua todos que se preocupam em defender a democracia e a soberania nacional. Teoricamente, é preciso produzir uma unificação política que permita a coesão dos setores progressistas, quer sejam partidos políticos ou movimentos sociais. Daí a importância de observar as TICs e as redes na política, para conquistar instrumentos que divulguem ideias capazes de assegurar a adesão do maior número de pessoas. Para fazer frente aos membros da rede conservadora, é urgente ampliar articulações políticas incluindo todos os atores que fazem política para ler e ver as formas alternativas de organização e conflitos políticos, para além dos partidos que estão rondando o mundo, para um projeto de nação que promova a reconstrução da soberania do país e que adote políticas em defesa dos brasileiros e do Brasil.

\section{BIBLIOGRAFIA}

ARENDT, H. Sobre a violência. Rio de Janeiro: Relumé-Dumará, 1994.

BEIRED, José Luiz Bendicho. A função social dos intelectuais. In: AGGIO, Alberto (Org.) Coutinho , N. Gramsci: a vitalidade de um pensamento. São Paulo, Editora UNESP, 1998.

BENTES, I. The impeachment was a fascist and conservative turn against culture. Journal of Latin American Cultural Studies, 27 (1), 2018.

BERBER SARDINHA, T. Linguística de Corpus. Barueri (SP): Manole, 2008.

BOURDIEU, P. Ofício de sociólogo. Metodologia da pesquisa na sociologia. Petrópolis (RJ): Vozes, 2007.

. O poder simbólico. Rio de Janeiro, Bertrand Brasil, 1998.

Bourdieu , P. BOURDIEU, Pierre. A distinção: crítica social do julgamento. São Paulo: Edusp; Porto Alegre, RS: Zouk, 2

BOBBIO, Norberto. Gramsci e o conceito de sociedade civil. São Paulo: Paz e Terra, 1999. . Contra os novos despotismos. São Paulo: Editora Unesp, 2016.

CASTELLS, M. A sociedade em rede. São Paulo: Paz e Terra, 1999. . Communication y Poder. Barcelona: Aliança Editorial, 2009. Ruptura: A crise da democracia libera,Rio de Janeiro, Editora Zahar, 2018.

COUTINHO, C. N. Socialismo e democracia: a atualidade de Gramsci. In: AGGIO, Alberto (Org.) Gramsci: a vitalidade de um pensamento. São Paulo: Editora UNESP, 1998.

EGLER, T. T. C. Política e espaço em crise. Rio de Janeiro, Letra Capital , 2017. 
FERGUSON, Niall. A praça e a torre. São Paulo: Planeta do Brasil, 2018.

FOUCAULT, M. Microfísica do poder. Rio de Janeiro: Graal, 1999.

GRAMSCI, A. Os intelectuais e a organização da cultura. Rio de Janeiro, Civilização Brasileira, 1979.

HARDT, M.; NEGRI, A. Império. Rio de Janeiro: Record, 2001.

KORYBKO, Andrew. Guerras hibridas, das revoluções coloridas aos golpes, São Paulo, Expressão Popular, 2018.

JOHNSON, S. Emergência: a dinâmica das redes. Em formigas, cérebros, cidades e softwares. Rio de Janeiro: Jorge Zahar Editor, 2003.

MARTÍN-BARBERO, J. Dos meios às mediações. Rio de Janeiro: Editora da UFRJ, 2009.

MORIN, Edgard. Por uma reforma do pensamento. In: Pena Vega, Alfredo e Elimar

Nascimento. O pensar Complexo: Edgard Morin e a crise da modernidade. Rio de Janeiro,

Garamond, 1999.

OLIVEIRA, Ricardo Costa et alli. Prosopografia familiar da operação "lava-jato" e do ministério Temer. REVISTA NEP-UFPR (Núcleo de Estudos Paranaenses da Universidade Federal do Paraná), Curitiba, v. 3, n. 3, p. 1-28, agosto 2017.

PENNA, Manoel Camillo, Frey , Klaus, Czarjkowski Jr. Avaliação Estrutural das redes sociotécnicas in Egler, Tamara Tania Cohen, Ciberpólis, redes no governo da cidade , Rio de janeiro, Editora Sete Letras, 2008.

RIBEIRO, A. C. T.; SILVA, C. A. Impulsos globais e espaço urbano: sobre o novo economicismo. In: RIBEIRO, A. C. T. (Ed.) El rostro urbano de América Latina. Buenos Aires: Clacso, p. 347-371, 2005.

RIBEIRO, A. C. T. Sociologia do presente: ação, técnica e espaço. Rio de Janeiro: Letra Capital Ed., 2012.

Teorias da ação. Rio de Janeiro: Letra Capital Ed., 2014.

SALMON, C. Storytelling, la machine a fabriquer des histoires et à formater les esprits. Paris: La Decouverte, 2007.

SINCLAIR, J. Corpus, Concordance, Collocations - Describing English Language. Universidade da Califórnia, 2008.

SOUZA, J. Radiografia do golpe: entenda como e por que você foi enganado. São Paulo: Leya Casa da Palavra, 2016.

TIBURI, Marcia. Delírio de poder: psicopoder e loucura coletiva na era da desinformação. Rio de Janeiro, Record, 2019.

VAN DIJK, T. How Globo media manipulated the impeachment of Brazilian President Dilma Rousseff. Discourse \& Communication, 11(2), 2017.

Páginas visitadas na Internet

Disponível em:<https://www.brasil247.com/pt/blog/carloslindenberg/339248/pesquisa-apontalula-foi-condenado-injustamente.htm>. Acesso em: 29 de janeiro de 2018/.

Disponívelem:<https://www.cartamaior.com.br/?/Editoria/Política/-Lula-e-a-joia-da-coroa-doPlano-Atlanta-/4/39191>. Acesso em: 19 de dezembro de 2017. 
Disponível em: <https://www.cartamaior.com.br/?/editoria/política/o-capital-financeitro-e-aeconomia-brasileira/4/31662>. Acesso em: 24 de agosto de 2014.

Disponível em: <https://www.cartacapital.com.br/revista/977/a-venda-do-pre-sal-um-desastrepara-o-brasil>. Acesso em: 30 de janeiro de 2018.

Disponível em:< http://www.esquerdadiario.com.br/quem-e-rogerio-chequer-lider-domovimento-vem-pra-rua-que-convoca-manifestacao-no-dia-04-12>. Acesso em: 3 de dezembro de 2016

Disponível em:< http://especiais.g1.globo.com/política/2016/processo-de-impeachment-dedilma/a-votacao-do-impeachment-na-camara/ >Acesso em: 17 de abril de 2016.

Disponível em:< http://especiais.g1.globo.com/política/2016/processo-de-impeachment-dedilma/a-votacao-da-procedencia-no-senado/ >Acesso em: 9 de agosto de 2016.

Disponível em:< http://política.estadao.com.br/blogs/fausto-macedo/janot-na-america-parafalar-sobre-delacao-e-combate-a-corrupcao/.> Acesso em: 14 de julho de 2017

Disponível em https://twitter.com/manolopich>. Acesso em: 19 de dezembro de 2017

Disponível em:< http://www.valor.com.br/brasil/5231447/estrangeiro-contorna-restricao-einveste-em-terra>. Acesso em: 19 de dezembro de 2017

Disponível em http:<://g1.globo.com/política/noticia/2015/02/eduardo-cunha-e-eleitopresidente-da-camara-dos-deputados.html> Acesso em: 1ำ de fevereiro de 2015

Disponível em www.conversaafiada.com.br/economia/boeing-quer-desmontar-a-embraer-elevar-para-os-eua/ >Acesso em: 22 de fevereiro de 2018.

Disponível em https:<://política.estadao.com.br/noticias/geral,pt-define-agenda-de-precampanha-de-lula-a-presiencia,70001917371>, acesso setembro de 2018

Disponível em https:<://www.brasildefato.com.br/2017/08/14/think-tanks-organizacoes-portras-da-guinada-da-direita-na-america-latina> acesso 23 de abril 2017

Disponível em https:<://www.cartamaior.com.br/?/Editoria/Antifascismo/Rede-Atlas-a-forcatarefa-dos-libertarios-de-ultradireita-por-tras-da-ofensiva-capitalista-na-America-Latina/ 47/41429/> acesso 13 de maio 2017

Disponível em https://www.cartamaior.com.br/?/Editoria/Antifascismo/Rede-Atlas-a-forcatarefa-dos-libertarios-de-ultradireita-por-tras-da-ofensiva-capitalista-na-America-Latina/ 47/41429> acesso 15 de maio 2017

Disponível em https://economia.uol.com.br/noticias/redacao/2014/03/03/ranking-debilionarios-da-forbes-traz-65-brasileiros-eike-fica-de-fora.htm>, acesso 12 de setembro, 2019

Disponível em https://g1.globo.com/política/noticia/2018/11/23/governo-bolsonaro-anunciasalim-mattar-para-secretaria-de-privatizacoes.ghtml>, acesso junho de 2019.

\section{NOTAS}

1. É preciso excluir de nossa análise a emergência de robots, que vem participando amplamente das redes sociais. Estamos nos referindo a redes com participação de pessoas.

2. https://www1.folha.uol.com.br/poder/2016/05/1774018-em-dialogos-gravados-juca-fala-empacto-para-deter-avanco-da-lava-jato.shtml

3. Departamento Intersindical de Assessoria Parlamentar (Diap). 
4. idem

5.

6. https://www.brasil247.com/pt/blog/carloslindenberg/339248/Pesquisa-aponta-Lula-foicondenado-injustamente.htm

7. https://www.trf4.jus.br/trf4/controlador.php?acao=pagina_menu_listar\&id_pai=166

8. Disponível em: <http://portal.stf.jus.br/> Acesso em: 16 dezembro 2019.

9. Disponível em: <http://www.in.gov.br/web/guest/inicio> Acesso em: 16 dezembro 2019.

10. Disponível em: <http://www.mpf.mp.br> Acesso em: 16 dezembro 2019.

11. Disponível em:<http://www.mpf.mp.br/grandes-casos/caso-lava-jato/atuacao-na-1ainstancia/parana/decisoes-da-justica> Acesso em: 16 dezembro 2019.

12. Disponível em:< http://www.mpf.mp.br/grandes-casos/caso-lava-jato/atuacao-na-1ainstancia/parana/linha-do-tempo> Acesso em: 16 dezembro 2019.

13. https://veja.abril.com.br/noticias-sobre/operacao-lava-jato/

14. https://theintercept.com/2019/06/09/editorial-chats-telegram-lava-jato-moro/

15. Idem

16. $\quad$ ttps://jornalggn.com.br/artigos/informacoes-do-the-intercept-provam-o-lawfare-comoarma-política-no-brasil-por-carol-proner-e-juliana-neuenschwander/

17.

18. https://economia.uol.com.br/noticias/redacao/2014/03/03/ranking-de-bilionarios-daforbes-traz-65-brasileiros-eike-fica-de-fora.htm,

19. http://divulgacandcontas.tse.jus.br/divulga/\#/consulta/campanha/2018/2022802018/ranks

20. https://economia.uol.com.br/noticias/redacao/2014/03/03/ranking-de-bilionarios-daforbes-traz-65-brasileiros-eike-fica-de-fora.htm

21. https://economia.uol.com.br/noticias/redacao/2014/03/03/ranking-de-bilionarios-daforbes-traz-65-brasileiros-eike-fica-de-fora.htm,

22. ( https://g1.globo.com/política/noticia/2018/11/23/governo-bolsonaro-anuncia-salimmattar-para-secretaria-de-privatizacoes.ghtml ,

23. https://política.estadao.com.br/noticias/geral,pt-define-agenda-de-pre-campanha-de-lula-apresiencia,70001917371

24. https://www.brasildefato.com.br/2017/08/14/think-tanks-organizacoes-por-tras-daguinada-da-direita-na-america-latina/

25. https://www.cartamaior.com.br/?/Editoria/Antifascismo/Rede-Atlas-a-forca-tarefa-doslibertarios-de-ultradireita-por-tras-da-ofensiva-capitalista-na-America-Latina/47/41429

\section{RESUMOS}

A questão proposta para análise é examinar como a tecnologia de informação e comunicação transforma a política, pela formação de redes sociotécnicas que associam diferentes atores e formam dois campos: o primeiro a favor de um discurso autoritário, e o outro de um discurso libertário. A hipótese considera a importância das TICs, tendo em vista que ela permite a coesão de atores no espaço de redes sociotécnicas e configura dois campos opostos, produz um conflito e cria uma instabilidade política. Para a realização da análise pretendida, o objeto empírico do conhecimento é decupado nas suas diferentes funções, como: judicialização da política; politização do judiciário; impulsão financeira; difusão simbólica; mobilização social. A pesquisa se 
desenvolve em torno de dois importantes fatos na política brasileira: o primeiro, associado ao impeachment da presidente Dilma Rouselff; o segundo, à condenação do presidente Luiz Inácio Lula da Silva. A metodologia envolve o levantamento de artigos em jornais, sua documentação em banco de dados, a análise dos discursos pelo programa AntConc, bem como análise da representação das redes pelo programa GEPHI. Os resultados analíticos revelam como o conflito simbólico entre os dois campos, conservador e progressista, se organiza por diferentes funções e forma uma macro rede sociotécnica de alta complexidade. Desvelam também como o discurso das redes conservadoras - que está associado à difusao de fake news numa complexa estratégia de manipulação da democracia, desenvolvida pela circulação da informação e da comunicação digital - dá ganho político ao projeto autoritário no Brasil.

The question proposed for analysis is to examine how information and communication technology transforms politics by forming sociotechnical networks that associate different actors and form two fields: the first in favor of an authoritarian discourse, and the other in a libertarian discourse. The hypothesis considers the importance of ICTs, considering that it allows the cohesion of actors in the space of sociotechnical networks and configures two opposing fields, produces a conflict, and creates a political instability. For the realization of the desired analysis, the empirical object of knowledge is decentered in its different functions, such as: judicialization of politics; politicization of the judiciary; financial drive; symbolic diffusion; social mobilization. The research is based on two important facts in Brazilian politics: the first, associated with the impeachment of President Dilma Rouselff; the second, to the condemnation of President Luiz Inácio Lula da Silva. The methodology involves the survey of articles in newspapers, their documentation in a database, the analysis of speeches by the AntConc program, as well as analysis of the representation of networks by the GEPHI program. The analytical results reveal how the symbolic conflict between the two fields, conservative and progressive, is organized by different functions and forms a macro socio technical network of high complexity. They also look at how the discourse of conservative networks - which is associated with the dissemination of fake news in a complex strategy of manipulation of democracy, developed by the circulation of information and digital communication - gives political gain to the authoritarian project in Brazil.

La pregunta que se propone para el análisis es examinar cómo las tecnologías de la información y la comunicación transforman la política, al formar redes sociotécnicas que asocian diferentes actores y forman dos campos: el primero a favor de un discurso autoritario y el otro en un discurso libertario. La hipótesis considera la importancia de las TIC, dado que permite la cohesión de actores en el espacio de redes socio-técnicas y configura dos campos opuestos, produce un conflicto y genera inestabilidad política. Para realizar el análisis pretendido, el objeto empírico de conocimiento se divide en sus diferentes funciones, tales como: judicialización de la política; politización del poder judicial; impulso financiero; difusión simbólica; movilización social. La investigación se desarrolla en torno a dos hechos importantes de la política brasileña: el primero, asociado al impeachment de la presidenta Dilma Rouselff; el segundo, a la condena del presidente Luiz Inácio Lula da Silva. La metodología involucra la recolección de artículos en periódicos, su documentación en una base de datos, el análisis de discursos por parte del programa AntConc, así como el análisis de la representación de redes por parte del programa GEPHI. Los resultados analíticos revelan cómo el conflicto simbólico entre los dos campos, conservador y progresista, está organizado por funciones diferentes y forma una macro red socio-técnica de alta complejidad. También revelan cómo el discurso de las redes conservadoras, que se asocia con la difusión de fake news en una compleja estrategia de manipulación de la democracia, desarrollada por la circulación de la información y la comunicación digital, da una ganancia política al proyecto autoritario en Brasil. 
La question d'analyse proposée est d'examiner comment les technologies de l'information et de la communication transforment la politique, à travers la formation de réseaux socio-techniques qui associent différents acteurs et forment deux domaines: le premier en faveur d'un discours autoritaire, et l'autre dans un discours libertaire. L'hypothèse considère l'importance des TIC, étant donné qu'elles permettent la cohésion des acteurs dans l'espace des réseaux sociotechniques et configure deux champs opposés, produit un conflit et crée une instabilité politique. Pour effectuer l'analyse envisagée, l'objet empirique de la connaissance est decoupage en ses différentes fonctions, comme: judiciarisation de la politique; politisation du pouvoir judiciaire; dynamisme financier; diffusion symbolique; mobilisation sociale. La recherche est développée autour de deux faits importants de la politique brésilienne: le premier, associé à impeachment de la présidente Dilma Rouselff; le second, la condamnation du président Luiz Inácio Lula da Silva. La méthodologie implique la collecte d'articles dans les journaux, leur documentation dans une base de données, l'analyse des discours par le programme AntConc, ainsi que l'analyse de la représentation des réseaux par le programme GEPHI. Les résultats analytiques révèlent comment le conflit symbolique entre les deux domaines, conservateur et progressif, est organisé par différentes fonctions et forme un macro-réseau socio-technique très complexe. Ils révèlent également comment le discours des réseaux conservateurs - qui est associé à la diffusion de fake news dans une stratégie complexe de manipulation de la démocratie, développée par la circulation de l'information et la communication numérique - donne un avantage politique au projet autoritaire au Brésil. Ils révèlent également comment le discours des réseaux conservateurs - qui est associé à la diffusion de fausses nouvelles dans une stratégie complexe de manipulation de la démocratie, développée par la circulation de l'information et la communication informatif - donne un avantage politique au projet autoritaire au Brésil.

\section{ÍNDICE}

Mots-clés: réseau sociotechnique; manipulation; autoritarisme; la démocratie; Brésil

Keywords: Sociotechnical network; Manipulation; Authoritarianism; Democracy; Brazil.

Palabras claves: red sociotécnica; manipulación; autoritarismo; democracia; Brasil.

Palavras-chave: rede sociotécnica; manipulação; autoritarismo; democracia; Brasil.

\section{AUTORES}

\section{TAMARA TANIA COHEN EGLER}

Professora titular do Instituto de Pesquisa e Planejamento Urbano e Regional da Universidade Federal do Rio de Janeiro. Coordenadora do INCT/CNPq - Políticas Públicas, inovação e desenvolvimento urbano. Pesquisadora 1B CNPq. Email: tamaraegler@gmail.com

\section{THIAGO COSTA PEREIRA}

Estudante de Física/UFRJ e de Análise e Desenvolvimento de Sistemas/Universidade Estácio de Sá e bolsista de Iniciação Científica do LabEspaço/IPPUR/UFRJ. Email: contato@tpereira.com.br.

\section{FABÍOLA DE CÁSSIA FREITAS NEVES}

Doutoranda em Planejamento Urbano e Regional do Programa de Pós-graduação em Planejamento Urbano e Regional e membro do LabEspaço da Universidade Federal do Rio de Janeiro. Email: fabiolafneves@hotmail.com. 